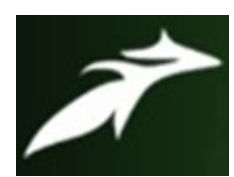

Maneesha Singh et al, International Journal of Advances in Agricultural Science \& Technology,

Vol.8 Issue.12, December-2021, pg. 11-31

ISSN: 2348-1358

Impact Factor: 6.057

NAAS Rating: 3.77

\title{
IMPACT OF ORGANIC AND BIOFERTILIZER APPLICATION ON YIELD AND YIELD ATTRIBUTING CHARACTERS IN LINSEED (Linum usitatissimum L.)
}

\author{
Maneesha Singh $^{1}$; Deeksha Chauhan ${ }^{2}$; Babita Bharti ${ }^{3}$ \\ ${ }^{1}$ School of Agricultural Sciences, Shri Guru Ram Rai University, Pathri Bagh, Uttarakhand, India \\ singhmaneesha2@gmail.com \\ ${ }^{2,3}$ Department of Agronomy, School of Agricultural Sciences, Shri Guru Ram Rai University, Pathri Bagh, \\ Uttarakhand, India \\ dikshachauhan757@gmail.com \\ DOI: 10.47856/ijaast.2021.v08i12.002
}

\begin{abstract}
:
Linseed (Linum usitatissimum L.) belongs to family Linaceae, is the second most important rabi oilseed crop and stands next to rapeseed - mustard in area of cultivation and seed production in India. Flaxseed is grown as either oil crop or a fibre crop with fibre linen derived from the stem of fibre varieties and oil from the seed of linseed varieties. Several studies have been conducted on effect of fertilizers on growth and yield of linseed (Linum usitatissimum L.) varieties which revealed their enhancing role on the quality and quantity of flax cultivars. In this regards, a present study was planned and conducted during the Rabi season of 2020-2021 in the Agricultural field of School of Agricultural Sciences, Shri Guru Ram Rai University, Dehradun, Uttarakhand, India to investigate the effect of organic and biofertilizer and integrated treatment on the growth and yield of Linseed. The findings were reported on important growth and yield attributed parameters such as plant height, total fresh weight, total yield, 1000- seed weight ( $\mathrm{g}$ ), and number of seed / capsules. The maximum growth and yield was reported in T6 treatment where biofertilizer have been applied in consortium form followed by vermicompost. Thus, the findings revealed that all the microbial strains in consortia used as bio fertilizers showed enhanced tern of vegetative growth of plants, total herbage yield and total seed yield at various stages. This may be due to sustained release of nutrients to supply the required elements in microbial strains. The biofertilizers exhibited beneficial effects on plant growth and development either through producing growth hormones like IAA, kinetin and gibberellins, synthesizing atmospheric nitrogen and its increased availability to greater protein synthesis as well as increasing Phosphorus availability to plant communities. Thus, it was concluded that the enhanced expression of yield and its related attributes will have beneficial impact in production of nutraceutical products of commercial importance.
\end{abstract}

Keywords: Linseed, biofertilizer, vermicompost, growth parameters, seed yield 


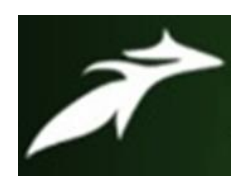

Maneesha Singh et al, International Journal of Advances in Agricultural Science \& Technology, Vol.8 Issue.12, December-2021, pg. 11-31

ISSN: 2348-1358

Impact Factor: 6.057

NAAS Rating: 3.77

\section{Introduction}

India has achieved a significant progress in agriculture production, particularly in cereals. However, from the point of dietary standards, economic and other associated consideration, the production of oilseed has been identified as the thrust area for stepping up oilseed production.

Production and processing of oilseed are important and crucial in Indian agriculture and economy. Presently 30 million farmers are engaged in the cultivation of oilseed on an area of 25.57 million hectares with the production of 28.20 million tonnes (Anonymous, 1994).

Oilseeds are the important sources for the realization of edible and non-edible oils. Edible oil supplement in preparation of dishes. On the other hand, non-edible oils are used in the manufacture of paints, varnishes, lubricants and in textiles. In addition, oilcakes are good sources of proteins for animal and poultry birds and have high export value. Major world oilseed crops are soybean, sunflower, Brassica, coconut, oil palm, rapeseed, peanuts, linseed.

Linseed of flax (Linum usitatissimum L., $2 \mathrm{n}=30, \mathrm{x}=15$ ) belongs to the order Malpighiales, family Linaceae, and the tribe Linear. It is the second most important rabi oilseed crop and stands next to rapeseed - mustard in area of cultivation and seed production in India. The genus Linum is compost of approximately 230 species, but cultivation linseed / flax is the only species the economic importance in the genus (Rowland et al., 1995) and is one of the oldest plants cultivated for fibre and oil. Linseed is popularly known as Alasi, Pesi, Phesi or Tisi in Odia. Flaxseed is grown as either oil crop or a fiber crop with fiber linen derived from the stem of fiber varieties and oil from the seed of linseed varieties (Erichen et al., 2003). About $20 \%$ of the total linseed oil produced in India is used by farmers and rest about $80 \%$ goes to industries for the manufacture of paints, varnish, oilcloth, linoleum and printing ink etc. Fibres obtained from the stem are known for their length and strength and are two to three times as strong as those of cotton (Taylor, 2012). The fibre is lustrous and blends very well with wool, silk and cotton etc. 


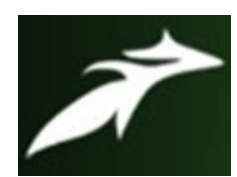

Maneesha Singh et al, International Journal of Advances in Agricultural Science \& Technology, Vol.8 Issue.12, December-2021, pg. 11-31

ISSN: 2348-1358

Impact Factor: 6.057

NAAS Rating: 3.77

Linseed plants have several utilities, it is cultivated commercially for its seed, which is processed into oil and after extraction of oil, and a high protein stock feed is left (Sankari, 2000; Kurt and Bozkurt, 2006). Linseed oil has been used for centuries as a drying oil whose oil content varies from 33-45\% (Gill, 1987). Flax is mainly grown in temperate areas.

Linseed has an important position in India economy due to its wide industrial utility. But the national average productivity of linseed seed is quite low as compared to other conditions in major linseed. Madhya Pradesh, Karnataka, Chhattisgarh, Jharkhand, Bihar, Maharashtra, Odisha, Uttar Pradesh, West Bengal, and Assam are major linseed growing states in the country. In India, annual oilseeds are cultivated over 26.67 million hectares of area producing 30.06 million tonnes annually (quinquennium ending 2016-2017). Majority of the oilseeds are cultivated under rainfed ecosystem (70\%). The area under oilseeds has experienced a deceleration in general, and this is due to their relative lower profitability against competing crops like maize, cotton, chickpea etc., under the prevailing crop growing and marketing situations. The cultivation of linseed can be used as an alternative in agriculture, which allows an increase in diversification of the production systems in temperate environments. However, in many regions where the traditional planting system is predominant, it is necessary to have an agro-economic incentive, to encourage the farmers to work with the linseed culture.

For an adequate plant development, it is necessary that a soil can supply its nutritional needs. This soil should provide adequate amounts of nutrients and ideal condition for plants to absorb them. According to Prado, the factor that affect the availability of nutrients in soil are: $\mathrm{pH}$, aeration, humidity, organic matter, temperature and presence of other ions.

With population pressure, soils nutrients and fertility decrease when farmers are not able to limit losses by adding nutrients to the soil through manures, crop residues, biofertilizers as well as chemical fertilizers. Regardless, the enormous use of chemical fertilizers in agriculture makes the country self-dependent in providing large amount of food supply but simultaneously damages the environment to a great extent and causes harmful impacts on living beings (Sujanya and Chandra, 2011). The indiscriminate uses of chemical fertilizer 


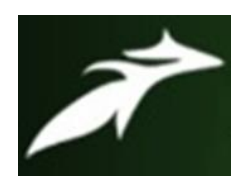

Maneesha Singh et al, International Journal of Advances in Agricultural Science \& Technology, Vol.8 Issue.12, December-2021, pg. 11-31

ISSN: 2348-1358

Impact Factor: 6.057

NAAS Rating: 3.77

show great threat to nature by polluting air, water, and soil (Savci, 2012). Since these hazardous chemicals can be haunted by the plants, they begin accumulating in spring water and a few of those chemicals also are liable for causing eutrophication of water bodies (Savci, 2012). These chemicals adversely affect soil in terms of depletion of water holding capacity, soil fertility, increased salinity, and disparity in soil nutrients. Considering all the adverse effects of prolonged use of chemical fertilizers, organic farming has emerged as a potent alternative area in terms of the growing demand of healthy food supply, long-term sustainability, and concerns regarding environmental pollution (Reddy, 2010). Although the use of chemical fertilizers is unavoidable to meet the rising demand of food in the world, there are opportunities where some selected crops and niche areas can be well flourished through organic farming (Macilwain, 2004; Chen, 2006). Several studies have been conducted on effect of fertilizers on growth and yield of linseed (Linum usitatissimum L.) varieties (Gaikwad et al., 2020).

Therefore, it is required to realize the various important and beneficial aspects of bio fertilizers and implementation of its application in modern agriculture. Although bio fertilizers possess a great potential to enhance the productivity of agricultural lands tremendously, the integrated approach to determine the most favourable plant microorganism interaction is the most crucial factor that results the augmentation in productivity. Keeping in view of above literature, the present investigation was undertaken to study the Impact of organic and bio fertilizer application on yield and yield attribute ng characters in Linseed (Linum usitatissimum L.).

\section{Research Methodology}

\section{Experimental site}

The field experiment was conducted during season of 2020-2021 in the experimental field of School of Agricultural Sciences, Shri Guru Ram Rai University, Dehradun, Uttarakhand. It is located in the North West region of Uttarakhand at an altitude of $450 \mathrm{~m}$ above mean sea level (MSL) and 3088 square kilometre in size. Geographically, the location of Dehradun is in between $29^{\circ} 58^{\prime}$ and $31^{\circ} 2^{\prime} 30^{\prime \prime}$ 'North latitude and $77^{\circ} 34^{\prime} 45^{\prime \prime}$ ' and $78^{\circ} 18^{\prime} 30^{\prime \prime}$ ' east longitudes. 


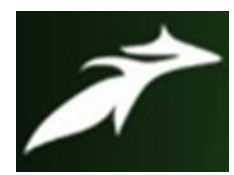

Maneesha Singh et al, International Journal of Advances in Agricultural Science \& Technology, Vol.8 Issue.12, December-2021, pg. 11-31

ISSN: 2348-1358

Impact Factor: 6.057

NAAS Rating: 3.77

\section{Climatic and weather conditions}

The climate of Dehradun is humid subtropical. Summer temperatures can reach up to $44^{\circ} \mathrm{C}$ for a few days and a hot wind called Loo blows over North India. Winter temperature is usually between 1 and $20^{\circ} \mathrm{C}$ and fog is quite common in winters like plains. Although the temperature in Dehradun can reach below freezing during severe cold snaps, this is not common, During the monsoon season, these is often heavy and protracted rainfall. Average Rainfall is $2074 \mathrm{~mm}$. Dehradun and other plain areas of Uttarakhand see almost as much rainfall as coastal Maharashtra and more than Assam. Agriculture benefits from fertile alluvial soil, adequate drainage and plentiful rain, it was recorded that Dehradun received $1734 \mathrm{~mm}$ rainfall from the month of July to October in 2020. The maximum and minimum temperature was recorded during the growing season of crop (November 2020 to April) was $25^{\circ} \mathrm{C}$ and $3^{\circ} \mathrm{C}$ respective.

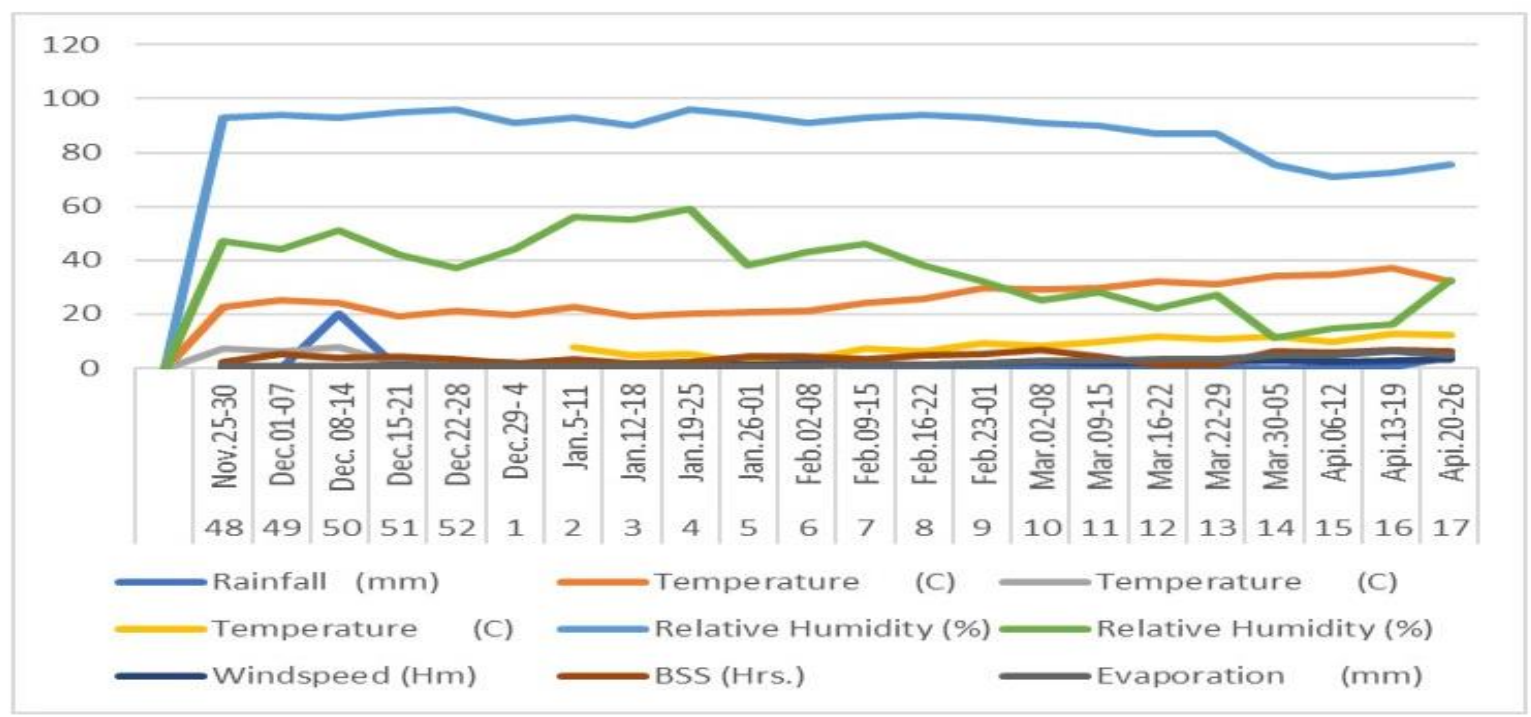

Figure 1. Weekly Meteorological Data during the period of Experimental (Rabi) Season (2020-2021)

\section{Soil characteristics}

The topography of experimental field was fairly uniform and levelled. In order to know the physical and chemical composition of experimental soil, samples were collected from experimental area and composite sample was prepared and analysed. The relevant data 


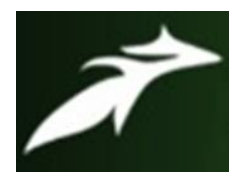

Maneesha Singh et al, International Journal of Advances in Agricultural Science \& Technology, Vol.8 Issue.12, December-2021, pg. 11-31

regarding the physical and chemical properties of experimental soil are presented in. The soil of the experimental field was sandy loam in texture. A composite sample was drawn after mixing up the entire sample homogeneously, which was used for mechanical and chemical analysis for determining the textural class and inherent fertility of the soil.

\section{Cropping history of experimental field}

Crop grown in the experimental field during Kharif and Rabi season in 2017, 2018, 2019 and 2020 are as follows:

Table 1: Cropping History of Experimental Field

\begin{tabular}{|c|l|l|}
\hline Year & Kharif & Rabi \\
\hline 2017 & Moong bean & Mustard \\
\hline 2018 & Urd bean & Lentil \\
\hline 2019 & Moong bean & Mustard \\
\hline 2020 & Urd bean & Mustard \\
\hline
\end{tabular}

\section{Experimental details:}

The experiment consists of 9 treatments, was planted in Randomized Block Design (RBD) and each set of treatment was replication for three times. Tiara (Jrf-2) variety was used for the experiment.

Table 2: Different combination of treatment used for experiments

\begin{tabular}{|l|c|}
\hline \multicolumn{1}{|c|}{ Treatment } & Symbol used \\
\hline $5 \mathrm{~kg}$ soil $+50 \mathrm{ml}$ NPK & $\mathrm{T} 1$ \\
\hline $5 \mathrm{~kg}$ soil $+50 \mathrm{gm}$ Pseudomonas & $\mathrm{T} 2$ \\
\hline $5 \mathrm{~kg}$ Soil $+25 \mathrm{ml} \mathrm{NPK}+25 \mathrm{gm}$ Pseudomonas & $\mathrm{T} 3$ \\
\hline $5 \mathrm{~kg}$ Vermicompost+ $50 \mathrm{ml} \mathrm{NPK}$ & $\mathrm{T} 4$ \\
\hline $5 \mathrm{~kg}$ Vermicompost+50 gm Pseudomonas & $\mathrm{T} 5$ \\
\hline $5 \mathrm{~kg}$ Vermicompost+ $25 \mathrm{ml} \mathrm{NPK}+25 \mathrm{gm}$ Pseudomonas & $\mathrm{T} 6$ \\
\hline $5 \mathrm{~kg}$ Vermicompost & $\mathrm{T} 7$ \\
\hline
\end{tabular}




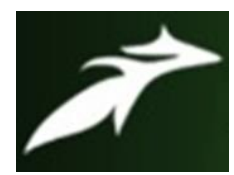

Maneesha Singh et al, International Journal of Advances in Agricultural Science \& Technology, Vol.8 Issue.12, December-2021, pg. 11-31

ISSN: 2348-1358

Impact Factor: 6.057

NAAS Rating: 3.77

\begin{tabular}{|l|c|}
\hline Sea Extract & T8 \\
\hline Control (Variety Tiara -Jrf-2) & T9 \\
\hline
\end{tabular}

\section{Cultural operation}

\section{Climate and soil}

Linseed is a cool season crop and requires moderate to cool temperature. It is grown best in well-drained, fertile, medium and heavy soils especially silty loam, clay loam and silty clays. This crop under cultivation in three ecosystems namely utera, rainfed and irrigated. Growing linseed in Utera, system is the predominant practice in Eastern States under paddy fallows.

\section{Sowing}

Sowing was done on $25^{\text {th }}$ November 2020 in furrows opened by hand plough to a depth 4$5 \mathrm{~cm} .25 \mathrm{~cm}$ seed were dropped by hand maintaining a definite quantity measured for each plot based on recommended seed rate $25-30 \mathrm{~kg} / \mathrm{ha}$. $600 \mathrm{gm}$ sowing of seeds, furrows were covered with thin layer of soil manually to avoid moisture loss.

\section{Irrigation and weeding}

$1^{\text {st }}$ irrigation was $25^{\text {th }}$ December, 2020 at the time of germination to provide and second irrigation was provided at the time of flowering.

As per treatment, one hand weeding was done at 90days within the help of khurpi. Hand weeding were done at 35-65 days after sowing. Weeding was done in rest of plots.

\section{Harvesting and threshing}

Harvesting of the crop was done in the month of April 2021 when crop attained full maturity. Before harvesting the representative simple plants from each net plot were taken out for postharvest. Harvested plants from the border area are excluded and the crop was left as such on the plot for sun during for one days. Harvesting is done with help of sickle manually. After sun drying, plant was tied up into bundles and tagged plot wise separately and then taken to the threshing to record the biological yield. Threshing is done manually by beating the plants with sticks. There after grain separate by winnowing of threshed materials and thus grain yield was recorded. 


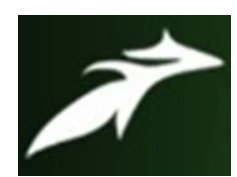

Maneesha Singh et al, International Journal of Advances in Agricultural Science \& Technology, Vol.8 Issue.12, December-2021, pg. 11-31

ISSN: 2348-1358

Impact Factor: 6.057

NAAS Rating: 3.77

\section{Economic}

The yield if linseed crop was convented into gross retum in rupees per hectare (Rs/ha) on the basis of prevalent price of produce in the market.

Net return was obtained by subtracting the cost of cultivation from gross retum of the individual treatment and is expressed in rupees per hectare (Rs/ha).

$$
\text { Net Return }(\mathrm{r} / \mathrm{ha})=\text { Gross Return }(\mathrm{r} / \mathrm{ha})-\text { Cost of Cultivation }(\mathrm{r} / \mathrm{ha})
$$

The benefit: cost ratio was calculated based on net return (Rs/ha) and cost of cultivation (Rs/ha) by following formula:

$$
\text { Benefit: Cost ratio }(\mathrm{BCR})=\frac{\text { Net Profit }(\mathrm{Rs} / \mathrm{ha})}{\text { Cost of cultivation }(\mathrm{Rs} / \mathrm{ha})}
$$

\section{Result and Discussion}

Linseed or, flax (Linum usitatissimum L.) is an important rabi seed oil crop next to mustard. It is also grown as fiber crop. Fiber is obtained from stem. Edible oil of Linseed is used for human consumption and contains poly unsaturated fatty acid such as $\alpha$-linolenic acid (ALA) that has nutritional and health benefits. Linseed is widely used as nutritional and functional food within the western world due to its high contents of therapeutic health promoting sustains like omega-3 fatty acid, soluble and insoluble fiber and lignin and its suitability to use with bread, breakfast cereals and other food products. Omega -3 fatty acid help to reduce the risk of cardiovascular disease and cancer (Gaikwad et al., 2020).

Majority of the oilseeds are cultivated under rainfed ecosystem (70\%). The area under oilseeds has experienced a deceleration generally and this is often due to their relative lower profitability against competing crops like maize, cotton, chickpea etc., under the prevailing crop growing and marketing situations. The cultivation of linseed is used as an alternate in agriculture, which allows a rise in diversification of the assembly systems in temperate environments.

Therefore, it should be essential for enhancing its productivity significantly within the next few decades to meet the demand of linseed both as fiber crop and oil crop. For fulfillment of 


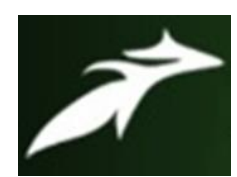

Maneesha Singh et al, International Journal of Advances in Agricultural Science \& Technology, Vol.8 Issue.12, December-2021, pg. 11-31

ISSN: 2348-1358

Impact Factor: 6.057

NAAS Rating: 3.77

this, it is necessary that the soil should provide adequate amounts of nutrients and ideal condition for plants to absorb them. Although synthetic fertilizers are replacing some soil nutrients fairly well, whether or not they will maintain or restore optimum soil health in perpetuity is yet to be seen. Organic fertilizers and soil microorganisms play a critical role in maintaining soil function because of their contribution to soil structure formation; decomposition of organic matter; toxin removal; and the biogeochemical cycling of $\mathrm{C}, \mathrm{N}, \mathrm{P}$, and S (Karlen et al., 1997; Doran and Zeiss, 2000; Paul, 2007). The magnitude of soil microbial diversity in agronomic soils is additionally imperative for the upkeep of healthy soil (Garbeva et al., 2004). Disregard for soil health will likely compromise future agricultural productivity in favour of high but short-term economic returns (Gliessman, 2007).

In view of above literature, linseed plants were selected for the present study to evaluate effect of application of organic and bio fertilizer on yield and yield attributing characters. The significant experimental finding obtained during the present investigation are discussed below with possible evidence wherever necessary in order to find out the effect relationship among different treatments with respect to various characters studied and sort out information of practical value.

\section{Effect of organic and bio fertilizer on growth parameters of linseed}

\section{Plant height}

The plant height was observed at the interval of 30 days i.e., 30, 60, 90 and at the time of harvesting. The plant height ranges from $4.2-19.3$ at 30 days. $26.6-61.0$ at 60 and 90 days. At the time of harvesting plant height ranges from 61.3 to $107.6 \mathrm{~cm}$. Maximum vegetative growth was seen between 30 to 60 days and 90 to at the time of harvesting in all the treatments. The maximum plant height $(19.3 \mathrm{~cm}, 63.3 \mathrm{~cm}, 85 \mathrm{~cm}$, and $105 \mathrm{~cm}$, respectively) was observed in case of treatment $\mathrm{T}_{6}(5 \mathrm{~kg}$ Vermicompost $+25 \mathrm{ml} \mathrm{NPK}$ consortia $+25 \mathrm{gm}$ Pseudomonas) during all the growth stages. Minimum plant height was observed in treatment $T_{9}$ (Control). 


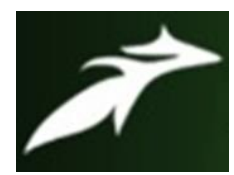

Maneesha Singh et al, International Journal of Advances in Agricultural Science \& Technology, Vol.8 Issue.12, December-2021, pg. 11-31

Increased in plant height at different growth stages may be due to secretion of cytokinin by the application of biofertilizers along with farmyard manure or vermicompost. A similar finding was noted by Waithaka and Dana (1978) on application of different levels of organic manures and biofertilizers singly or in combination show significant variation on days required to flower bud appearance after pruning. Similar findings were observed in case of maize where many research studies have showed that the composted organic materials release nutrients slowly and may reduce the leaching losses, particularly $\mathrm{N}$ (Nevens and Reheul, 2003 and Naveed et al., 2008). Biofertilizers enhance plants growth by increasing the availability of primary nutrients and stimulate targeted plant growth when inoculated on seed, applied on plant surface or on soil (Muraleedharan et al., 2010).

Table 3. Plant height of linseed at different growth stages

\begin{tabular}{|c|c|c|c|c|c|c|c|c|}
\hline \multirow{2}{*}{ Treatment } & \multicolumn{2}{|c|}{30 Days } & \multicolumn{2}{c|}{ 60 Days } & \multicolumn{2}{c|}{ 90 Days } & \multicolumn{2}{c|}{ At Harvest } \\
\cline { 2 - 9 } & Mean & \pm SE & Mean & \pm SE & Mean & \pm SE & Mean & \pm SE \\
\hline $\mathrm{T}_{1}$ & 6.5 & 0.29 & 32.3 & 1.45 & 32.33 & 1.85 & 71.6 & 1.67 \\
\hline $\mathrm{T}_{2}$ & 7.6 & 0.44 & 35.6 & 2.02 & 35.66 & 0.67 & 86.6 & 0.88 \\
\hline $\mathrm{T}_{3}$ & 13.0 & 1.73 & 44.5 & 1.60 & 44.5 & 1.77 & 74.66 & 2.02 \\
\hline $\mathrm{T}_{4}$ & 5.53 & 0.30 & 33.3 & 1.66 & 33.3 & 2.03 & 87.0 & 1.52 \\
\hline $\mathrm{T}_{5}$ & 7.56 & 0.31 & 36.3 & 1.85 & 36.3 & 1.45 & 75.33 & 1.45 \\
\hline $\mathrm{T}_{6}$ & 19.3 & 0.30 & 61.0 & 2.08 & 61.0 & 1.45 & 107.6 & 1.45 \\
\hline $\mathrm{T}_{7}$ & 8.5 & 0.29 & 37.6 & 1.45 & 37.66 & 1.73 & 92.3 & 1.45 \\
\hline $\mathrm{T}_{8}$ & 6.5 & 0.28 & 33.6 & 1.66 & 33.33 & 1.45 & 83.0 & 1.52 \\
\hline $\mathrm{T}_{9}$ & 4.2 & 0.14 & 26.6 & 0.88 & 26.66 & 1.45 & 61.3 & 1.85 \\
\hline$\pm \mathrm{SE}$ & 1.55 & & 3.30 & & 3.30 & & 4.48 & \\
\hline
\end{tabular}




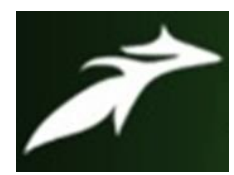

Maneesha Singh et al, International Journal of Advances in Agricultural Science \& Technology,

Vol.8 Issue.12, December-2021, pg. 11-31

ISSN: 2348-1358

Impact Factor: 6.057

NAAS Rating: 3.77

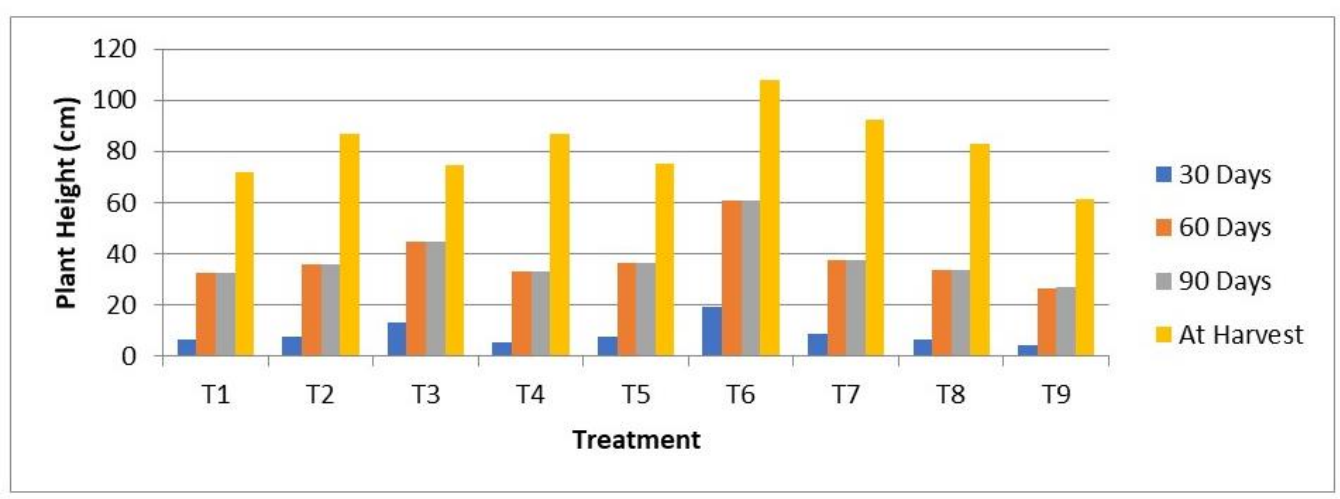

Figure 2. Plant height $(\mathrm{cm})$ of Linseed at a different growth stage

\section{Total fresh weight of linseed plant at the time of harvesting}

Fresh weight of linseed plant ranges from $3.52 \mathrm{~kg}$ to $9.31 \mathrm{~kg}$ in all the treatments along with control. Significant data has been recorded in all the treatments. Maximum total fresh weight per plot was recorded under $\mathrm{T}_{8}$ i.e., $5 \mathrm{~kg}$ Vermicompost $+25 \mathrm{ml}$ NPK consociate $+25 \mathrm{gm}$ Pseudomonas $(9.31 \mathrm{~kg})$. The lowest total fresh weight was observed under $\mathrm{T}_{9}$ control $(3.52 \mathrm{~kg})$.

The increase in growth attributes along with increase in yield was due to microorganisms that are present in bio-fertilizers, which stimulates the plants growth by supplying nutrients by their colonization at the rhizosphere or, by their symbiotic association. The association regulates the physiological process in the ecosystem, by the involvement of organic matter decomposition and atmospheric nitrogen fixation (Rajasekaran et al., 2015; Rachel\& Sirisha, 2015).

Table 4. Total fresh weight (kg) of linseed plant at the time of harvesting

\begin{tabular}{|c|c|c|}
\hline \multirow{2}{*}{ Treatment } & \multicolumn{2}{|c|}{ At harvest } \\
\cline { 2 - 3 } & Mean & \pm SE \\
\hline $\mathrm{T}_{1}$ & 7.69 & 0.09 \\
\hline $\mathrm{T}_{2}$ & 6.59 & 0.12 \\
\hline $\mathrm{T}_{3}$ & 7.8 & 0.08 \\
\hline $\mathrm{T}_{4}$ & 6.5 & 0.18 \\
\hline
\end{tabular}




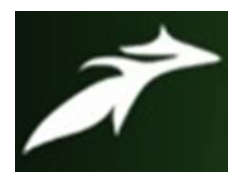

Maneesha Singh et al, International Journal of Advances in Agricultural Science \& Technology, Vol.8 Issue.12, December-2021, pg. 11-31

ISSN: 2348-1358

Impact Factor: 6.057

NAAS Rating: 3.77

\begin{tabular}{|c|c|c|}
\hline $\mathrm{T}_{5}$ & 5.79 & 0.06 \\
\hline $\mathrm{T}_{6}$ & 9.31 & 0.16 \\
\hline $\mathrm{T}_{7}$ & 5.0 & 0.34 \\
\hline $\mathrm{T}_{8}$ & 6.5 & 0.18 \\
\hline $\mathrm{T}_{9}$ & 3.52 & 0.23 \\
\hline$\pm \mathrm{SE}$ & 0.56 & \\
\hline
\end{tabular}

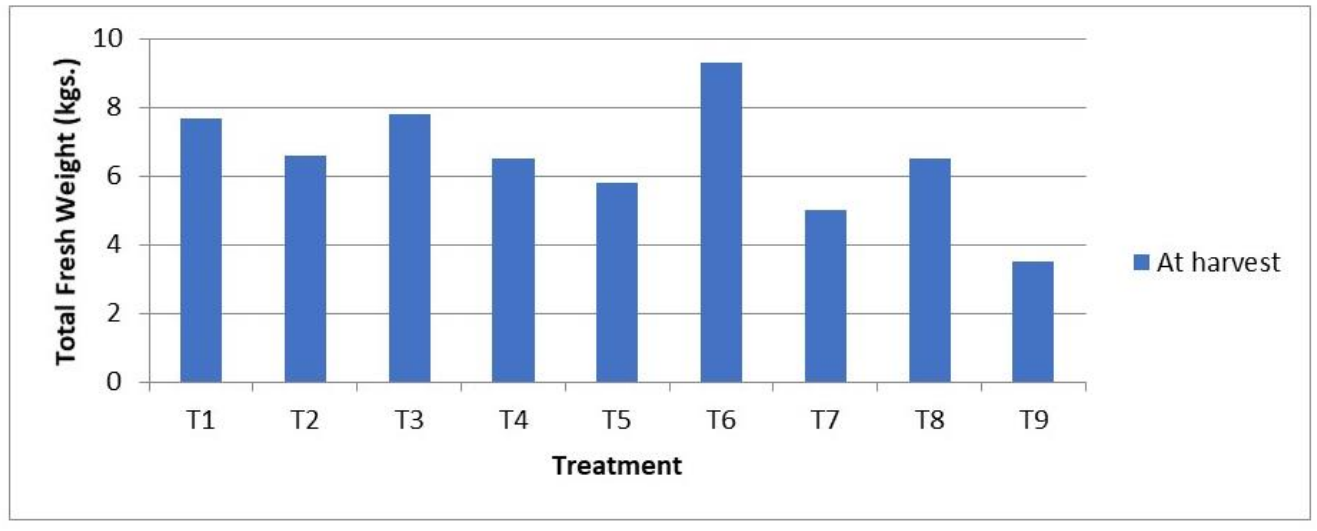

Figure 3. Total Fresh Weight of Linseed plant at the time of Harvesting

\section{Effect of organic and bio fertilizer on total seed yield (q/ha)}

Significantly higher seed yield was recorded with the application of $5 \mathrm{~kg}$ Vermicompost $+25 \mathrm{ml}$ $\mathrm{NPK}+25 \mathrm{gm}$ Pseudomonas $\left(\mathrm{T}_{6}\right)(20.16 \mathrm{q} / \mathrm{ha})$ that remained statistically at par with $\mathrm{T}_{3}(18.89 \mathrm{q} / \mathrm{ha}), \mathrm{T}_{7}$ (18.18) treatment and the lowest value was recorded under $\mathrm{T}_{8}(9.25 \mathrm{q} / \mathrm{ha})$.

Kumaran et al. (1998) recorded significantly highest growth and yield of Ocimum grattisimum with combined application of inorganic fertilizers and biofertilizers. Maheshwari et al. (1991) reported that Azotobacter gave alone significantly higher herbage of palmarosa compared to control under rainfed condition. Kumar et al. (2002) also supported the above 


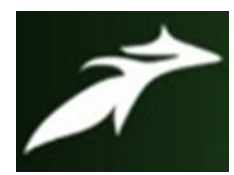

Maneesha Singh et al, International Journal of Advances in Agricultural Science \& Technology, Vol.8 Issue.12, December-2021, pg. 11-31

ISSN: 2348-1358

Impact Factor: 6.057

NAAS Rating: 3.77

findings. According to him, the combined inoculation of coriander seed with Azotobacter and Azospirillum increased the seed, Stover yield and harvest index significantly.

The vermicompost and biofertilizers exhibited beneficial effects on plant growth and development either through producing growth hormones like IAA, kinetin, and Gibberellins, synthesizing atmospheric nitrogen and it increased availability to greater protein synthesis (Pandey and Kumar, 1989) as well as increasing P availability to plant communities (Bolan, 1991, Phule et al., (1993). Dharmalingam et al. (1995) studies the effect of vermicompost pellected soybean seed and reported $16 \%$ increase in yield over non pellected seeds. Rajalakshmi et al., (1997) in their studies on various organic manures in combination with chemical fertilizer NPK at $75: 40: 25 \mathrm{~kg} / \mathrm{ha}^{-1}$ on chillies found that the yield was highest $\left(8.36 \mathrm{ha}^{-1}\right)$ in the treatment receiving vermicompost- NPK fertilizers and the lowest in vermiculture alone. Among the various organic manures, incorporation of vermicompost was considered as the best in improving all the characters.

Table 5. Total Seed Yield (q/ha) of Linseed plant

\begin{tabular}{|c|c|c|c|}
\hline \multirow{2}{*}{ S. No } & \multirow{2}{*}{ Treatment } & \multicolumn{2}{|c|}{ Total seed yield (q/ha) } \\
\cline { 3 - 4 } & & Mean & $\mathbf{\pm S E}$ \\
\hline 1 & $\mathrm{~T}_{1}$ & 15.00 & 1.21 \\
\hline 2 & $\mathrm{~T}_{2}$ & 13.52 & 1.52 \\
\hline 3 & $\mathrm{~T}_{3}$ & 18.89 & 1.21 \\
\hline 4 & $\mathrm{~T}_{4}$ & 16.14 & 1.21 \\
\hline 5 & $\mathrm{~T}_{5}$ & 16.63 & 1.52 \\
\hline 6 & $\mathrm{~T}_{6}$ & 20.16 & 1.46 \\
\hline 7 & $\mathrm{~T}_{7}$ & 18.18 & 0.88 \\
\hline 8 & $\mathrm{~T}_{8}$ & 12.36 & 1.53 \\
\hline 9 & $\mathrm{~T}_{9}$ & 9.25 & 0.89 \\
\hline & $\pm \mathrm{SE}$ & 1.15 & \\
\hline
\end{tabular}




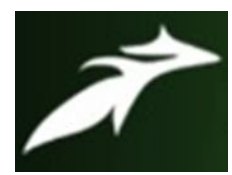

Maneesha Singh et al, International Journal of Advances in Agricultural Science \& Technology, Vol.8 Issue.12, December-2021, pg. 11-31

ISSN: 2348-1358

Impact Factor: 6.057

NAAS Rating: 3.77

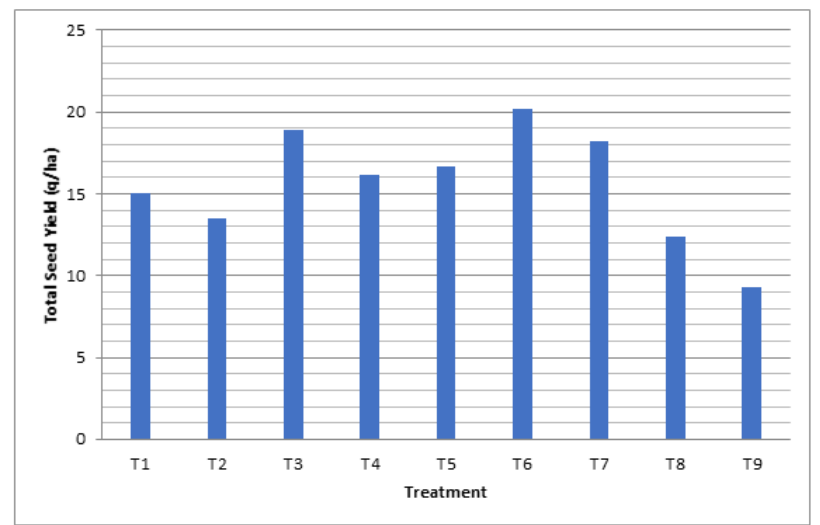

Figure 4. Total Seed Yield (q/ha) at different growth stages of Linseed

\section{0- Seed weight $(\mathrm{g})$}

Test weight (1000gm seed weight) of linseed was significantly heights treatment T6 recorded the maximum 1000-seed weight $(7.51 \mathrm{~g})$. The lowest value was recorded seed/capsule under $\mathrm{T}_{9}$ (7.05).

Table 6. 1000- Seed Weight (g)

\begin{tabular}{|c|c|c|}
\hline \multirow{2}{*}{ Treatment } & \multicolumn{2}{|c|}{ 1000 - Seed weight (g) } \\
\cline { 2 - 3 } & Mean & $\mathbf{\pm S E}$ \\
\hline $\mathrm{T}_{1}$ & 7.34 & 0.043 \\
\hline $\mathrm{T}_{2}$ & 7.26 & 0.020 \\
\hline $\mathrm{T}_{3}$ & 7.16 & 0.029 \\
\hline $\mathrm{T}_{4}$ & 7.49 & 0.023 \\
\hline $\mathrm{T}_{5}$ & 7.24 & 0.023 \\
\hline $\mathrm{T}_{6}$ & 7.51 & 0.028 \\
\hline $\mathrm{T}_{7}$ & 7.48 & 0.01 \\
\hline $\mathrm{T}_{8}$ & 7.24 & 0.980 \\
\hline $\mathrm{T}_{9}$ & 7.05 & 0.011 \\
\hline$\pm \mathrm{SE}$ & 0.050 & \\
\hline
\end{tabular}




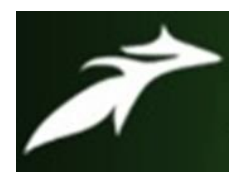

Maneesha Singh et al, International Journal of Advances in Agricultural Science \& Technology,

Vol.8 Issue.12, December-2021, pg. 11-31

ISSN: 2348-1358

Impact Factor: 6.057

NAAS Rating: 3.77

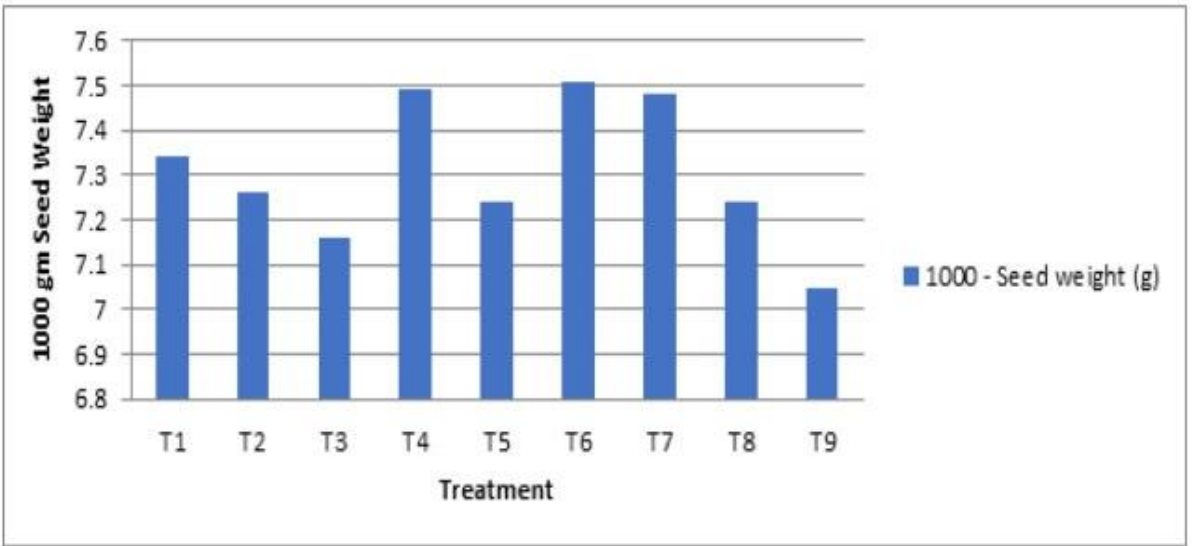

Figure 5. 1000 gm seed weight

\section{Number of seeds per capsule linseed plants}

Significantly higher Number of seed/ Capsule was recorded with the application of $5 \mathrm{~kg}$ Vermicompost $+25 \mathrm{ml} \mathrm{NPK}+25 \mathrm{gm}$ Pseudomonas $\mathrm{T}_{6}(9.54)$ capsule. The lowest value was recorded seed/capsule under $\mathrm{T}_{9}(9.01$ Capsule).

The maximum number of seed per capsule at lowest position capsule indicated that condition at the time of first capsule formation and development were more favourable i.e., temperature and maximum availability of photosynthates as most of the leaves were green having maximum photosynthetic capacity. Progressive reduction in number of seed/capsules might be the effect of temperature variation. The different in mean temperature from start to the end of capsule. The importance of number of capsules as determinant factor of drop yield was reported in earlier research and they concluded that capsule number needs to consider as an important yield limiting factor (Copur et al., 2006). 


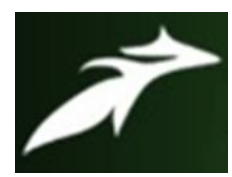

Maneesha Singh et al, International Journal of Advances in Agricultural Science \& Technology, Vol.8 Issue.12, December-2021, pg. 11-31

Table 7. Number of seeds per capsule in linseed plants

\begin{tabular}{|c|c|c|c|}
\hline \multirow{2}{*}{ S. No } & \multirow{2}{*}{ Treatment } & \multicolumn{2}{|c|}{ Number of seeds per capsule } \\
\cline { 2 - 4 } & & Mean & $\mathbf{\pm S E}$ \\
\hline 1 & $\mathrm{~T}_{1}$ & 9.04 & 0.01 \\
\hline 2 & $\mathrm{~T}_{2}$ & 9.14 & 0.01 \\
\hline 3 & $\mathrm{~T}_{3}$ & 9.03 & 0.01 \\
\hline 4 & $\mathrm{~T}_{4}$ & 9.45 & 0.01 \\
\hline 5 & $\mathrm{~T}_{5}$ & 9.06 & 0.01 \\
\hline 6 & $\mathrm{~T}_{6}$ & 9.54 & 0.02 \\
\hline 7 & $\mathrm{~T}_{7}$ & 9.42 & 0.01 \\
\hline 8 & $\mathrm{~T}_{8}$ & 9.08 & 0.03 \\
\hline 9 & $\mathrm{~T}_{9}$ & 9.01 & 0.01 \\
\hline & $\pm \mathrm{SE}$ & 0.01 & \\
\hline
\end{tabular}

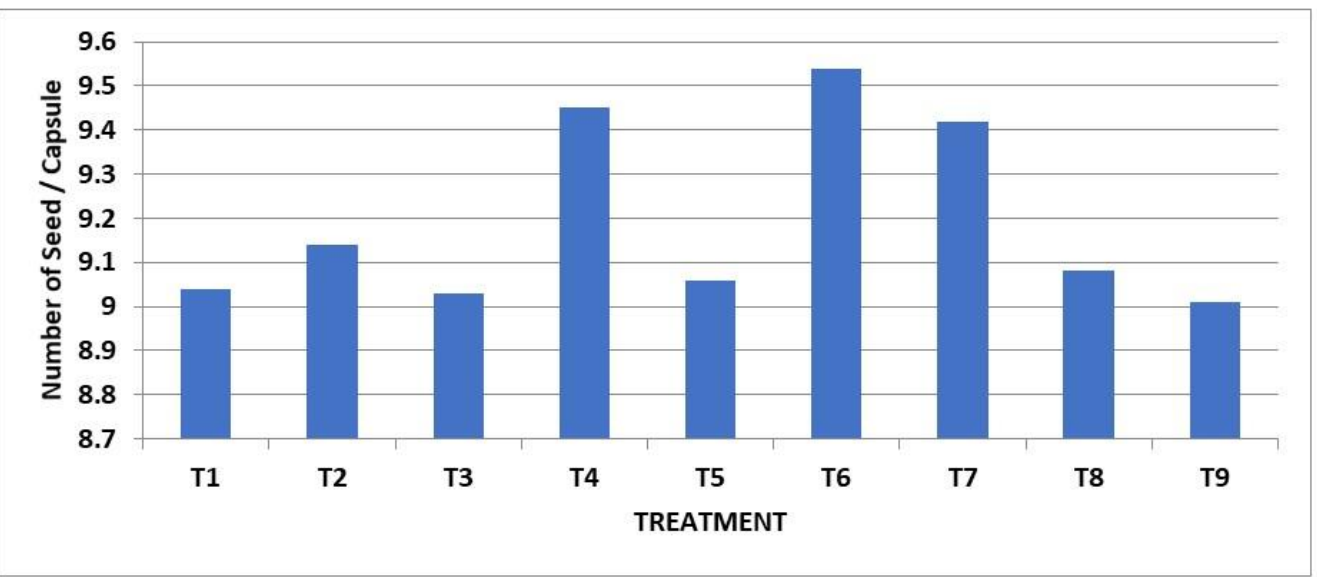

Figure 6. Number of Seed/Capsules 


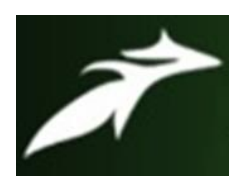

Maneesha Singh et al, International Journal of Advances in Agricultural Science \& Technology, Vol.8 Issue.12, December-2021, pg. 11-31

ISSN: 2348-1358

Impact Factor: 6.057

NAAS Rating: 3.77

\section{Economics of production}

The higher yield was attributed to the higher plant growth development including greater plant height, number of branches, and total fresh weight per plant. The beneficial effect of organic manures on plant growth and development has been well established by Vadiraj et al., (1998) in his studies. Data pertaining to gross return (q/ha.), net return (/h) and benefitcost ratio as affected by organic bio fertilizer treatment have been summarized by presented in table 8 .

The influence of different organic fertilizer and bio fertilizer treatment on gross return (Rs/ha) was well market. All the treatment registered significantly higher gross return over the treatment. The maximum gross return (383040/-) was obtained under treatment $\mathrm{T}_{6}$. The minimum gross return (175750/-) was obtained under $\mathrm{T}_{9}$ Treatment. Different treatment showed market effect on the net return $(\mathrm{Rs} / \mathrm{ha})$. All the treatment $\mathrm{T}_{8}$ although generate the highest net return (358040/-). The minimum net return (150750/-) was observed in $\mathrm{T}_{9}$. Different treatment significantly influenced the benefit cost ratio. Maximum benefit cost ratio was obtained with the treatment $\mathrm{T}_{6}(15.32)$. The minimum benefit cost ratio (7.03) $\mathrm{T}_{9}$.

The biofertilizers including phosphorus improved the soil fertility by resulting into higher accumulation of humic substances and microbial population in the soil that improved the availability of macro as well as micronutrients and finally higher photosynthesis. Similarly, Singh and Ramesh (2002) noticed that significantly higher plant height and seed yield of Ocimum basilicum with application of vermicompost @ $2.5 \mathrm{t} \mathrm{ha}^{-1}$. Chand et al. (1996) also found similar findings in Jamrosa, Slawinski and Songin (2001) in Pea, Paturde et al. (2002) in Chlorophytum borivallianum and in Davana (Artemisia pallens) by Chalapathi et al. (2004). 


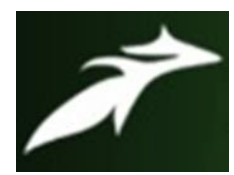

Maneesha Singh et al, International Journal of Advances in Agricultural Science \& Technology, Vol.8 Issue.12, December-2021, pg. 11-31

ISSN: 2348-1358

Impact Factor: 6.057

NAAS Rating: 3.77

Table 8: Gross Return (Rs/ha), Net Return (Rs/ha) and Benefit - Cost Ratio of different Treatments

\begin{tabular}{|c|c|c|c|c|}
\hline $\begin{array}{l}\text { S. } \\
\text { No }\end{array}$ & Treatment & $\begin{array}{l}\text { Gross Return } \\
\quad(\mathrm{Rs} / \mathrm{ha})\end{array}$ & $\begin{array}{l}\text { Net Return } \\
\text { (Rs/ha) }\end{array}$ & $\begin{array}{l}\text { B:C } \\
\text { Ratio }\end{array}$ \\
\hline 1 & $\mathrm{~T} 1(5 \mathrm{~kg}$ soil $+50 \mathrm{ml}$ NPK consortia $)$ & 285000 & 260000 & 10.4 \\
\hline 2 & $\mathrm{~T} 2(5 \mathrm{~kg}$ soil +50 gm Pseudomonas $)$ & 256880 & 231880 & 10.27 \\
\hline 3 & $\begin{array}{l}\mathrm{T} 3(5 \mathrm{~kg} \text { Soil }+25 \mathrm{ml} \text { NPK consortia }+25 \\
\text { gm Pseudomonas) }\end{array}$ & 358910 & 333910 & 14.35 \\
\hline 4 & $\begin{array}{l}\mathrm{T} 4 \text { ( } 5 \mathrm{~kg} \text { Vermicompost }+50 \mathrm{ml} \mathrm{NPK} \\
\text { consortia) }\end{array}$ & 306660 & 281660 & 12.26 \\
\hline 5 & $\begin{array}{l}\text { T5 ( } 5 \mathrm{~kg} \text { Vermicompost }+50 \mathrm{gm} \\
\text { Pseudomonas) }\end{array}$ & 315970 & 290970 & 12.63 \\
\hline 6 & $\begin{array}{l}\mathrm{T} 6(5 \mathrm{~kg} \text { Vermicompost }+25 \mathrm{ml} \mathrm{NPK} \\
\text { consortia }+25 \mathrm{gm} \text { Pseudomonas })\end{array}$ & 383040 & 358040 & 15.32 \\
\hline 7 & T7 (5 kg Vermicompost) & 345420 & 320420 & 13.89 \\
\hline 8 & T8 (Sea Extract) & 234840 & 209840 & 9.39 \\
\hline 9 & T9 (Control) & 175750 & 150750 & 7.03 \\
\hline
\end{tabular}

\section{Conclusion}

The present study has revealed that there is a huge potential for the use of bio-fertilizer in a wide variety of crop plants. Application of bio-fertilizer promote healthy growth and yield of plants along with enhancing sustainability of soil. Therefore, linseed must be grown successfully with combined application of Vermicompost + bio fertilizers for higher values with sustained the soil of tarai region is very fertile and support to number of crops district Dehradun Uttarakhand. Finally, it was concluded that combined application of organic as well as bio fertilizers played more effective role both for quantitative characters as compare to single application of them. This will reduce the cost if cultivation and improve soil fertility. 


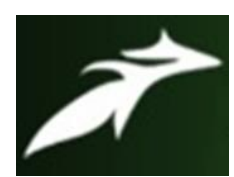

Maneesha Singh et al, International Journal of Advances in Agricultural Science \& Technology, Vol.8 Issue.12, December-2021, pg. 11-31

ISSN: 2348-1358

Impact Factor: 6.057

NAAS Rating: 3.77

\section{References}

[1]. Anonymous 1994, Atlas pesquero de Mexico. Instituto Nacional de la Pesca.234 p.

[2]. Bolan N.S., 1991, A critical review on the role of mycorrhizal fungi in the uptake of phosphorus by plants. Plant and Soil. 134: 189-207.

[3]. Bouyoucus G.J., 1962, Direction for making mechanical analysis of soil by hydrometer method. Soil Science, 42: 225-228.

[4]. Casamayor A., Torrance P.D., Kobayashi T., Thorner J., Alessi D.R., 1999, Function counterparts of mammalian protein kinases PDK1 and SGK in budding yeast. Curr. Biol, 9 (4): 186-97.

[5]. Chalapathi M.V., Vashundhara M., Gangadhar Eawar Rao G., Thimmegowda E.V.S., Prakasa Rao and Deva Kumar N. (2004). Influence of integrated nutrient management on yield of davana (Artemisia pallens). Indian Perfumer. 48 (3): 331-316.

[6]. Chand S., Kaul P.N., Bhattacharya A.K., Singh K., Singh C.P. and Rajeswara Rao B.R. 1996, Response of Jamrosa (Cymbopogon species) to spacing, FYM, nitrogen, phosphorus and zinc. Indian Perfumer, 40 (2): 41-46.

[7]. Chen J.H., 2006, The combined use of chemical and organic fertilizers and/or biofertilizers for crop growth and soil fertility, international workshop on sustained management of the soil-rhizosphere system for efficient crop production and fertilizer use, 16 - 20 October, Land development department, Bangkok, Thailand.

[8]. Copur O., Karakus M., Demirel U, 2006, Department of correlation and path analysis among yield components and seed yield in flax varieties (Linum usitatissimum L.). J. Bio. Sci., 6: 738-743.

[9]. Dawood M.G., Sadak M.S., Abdallah M.M. S., 2019, Influence of biofertilizers on growth and some biochemical aspects of flax cultivars grown under sandy soil conditions. Bull Nat. Res. Cent., 43: 81.

[10].Dexter A.R., 1988. Advances in characterization of soil structure. Soil and Tillage Research. 11: 199238.

[11].Dharmalingam C., Maheswari R. and Nargis S. 1995, Vermicompost and total seed pelleting for enhanced productivity in field crops. Proceedings of national workshop on tropical organic farming, 25-28 September, Coimbatore, pp.56-59.

[12].Doran J.W., 2000, Soil health and global sustainability: Translating science into practice. Agriculture, Ecosystems and Environment. 88:119-127.

[13].Doran J.W. and Zeiss M.R., 2000, Soil health and sustainability: managing the biotic components of soil quality. Applied Soil Ecology, 15:3-11.

[14].Erichsen K., Hausken T., Ulvik R.J., Svardal A., Berstad A., Berge R.K., 2003, Ferrous fumarate deteriorated plasma antioxidant status in patients with Crohn disease. Scand $J$ Gastroenterol., 38(5):543-8.

[15].Gaikwad S.R., Suryavanshi V.P., Bhusari S.A. and Misal A.M., 2020). Effect of fertilizers on growth and yield of linseed (Linum usitatissimum L.) varieties. The Pharma Innovation Journal. 9(10):127-131.

[16].Gaikwad U., Jalali R., 2020 Differentiating radiation necrosis vis-a-vis recurrence in brain metastasis. Cancer Res Stat Treat. 3:414-5.

[17].Garbeva P., Van Veen J.A., and Van Elsas J.D., 2004, Microbial diversity in soil: selection of microbial population by plant and soil type and implication for soil suppressiveness. Annual review of Phytopathology, 42: 243-270.

[18].Gliessman S.R., 2007, Agroecology: The Ecology of sustainable food systems. $2^{\text {nd }}$ ed. CRC Press, Boca Raton, FL.

[19].Huh, Gill Haeng, 1987, Improving the Agricultural Marketing at Producing Areas in Korea, KREI. Journal of Rural Development, 155 - 16

[20].Karlen D.L., Mausbach M.J., Doran J.W., Cline R.G., Harris R.F., and Shuman G.E., 1997, Soil quality: A concept, definition, and framework for evaluation. Soil Society American Journal, 61: 4-10.

[21].Kumar S., Choudhary G.R. and Choudhary A.C., 2002, Effect of nitrogen and bio- fertilizers on yield and quality of coriander (Coriandrum sativum L.). Ann. Agic. Res. New Series, 23 (4): 634 - 637. 


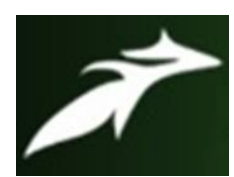

Maneesha Singh et al, International Journal of Advances in Agricultural Science \& Technology, Vol.8 Issue.12, December-2021, pg. 11-31

ISSN: 2348-1358

Impact Factor: 6.057

NAAS Rating: 3.77

[22].Kumaran S.S., Natajaran S. and Thamburaj S., 1998, Effect of organic inorganic fertilizers on growth, oil yield and quality of Ram Tulsi. South Indian Horticulture, 46 (3-6): 203 -205.

[23].Kurt O., and Bozkurt D., 2006, Effect of temperature and photoperiod on seedling emergence of flax (Linum usitatissimum L.). Journal of Agronomy, 5: 541-545.

[24].Macilwain Colin, 2004, Organic: Is it the future of farming? Nature, 428:792-3.

[25].Maheshwari S.K., Joshi R.C., Gangrade G.S., Choudhan G.S. and Trivedi K.C. 1991, Effect of farm yard manure and zinc on rainfed palmarosa oil grass. Indian Perfumer, 32 (4): 226-229.

[26].Muraleedharan H., Seshadri S. and Perumal K, 2010, Biofertilizer (Phosphobacteria), Booklet published by Shri AMM Murugappa Chettiar Research Centre, Taramani, Chennai-600113.

[27].Naveed M., Khalid M., Jones D.L., Ahmad R., and Zahir Z.A., 2008, Relative efficiency of Pseudomonas spp., containing ACC-deaminase for improving growth and yield of maize (Zea mays L.) in the presence of organic fertilizer. Pak. J. Bot., 40(3): 1243-1251.

[28].Nevens F. and Reheul D., 2003, The application of vegetable, fruit and garden waste (VFG) compost in addition to cattle slurry in a silage maize monoculture: nitrogen availability and use. European Journal of Agronomy, 19:189-20.

[29].Pandey A. and Kumar S., 1989, Potential of Azotobaceter and Azospirilium as biofertilizers for upland agriculture. A review. Journal of Scientific and Industrial Research, 48 (48): 134-144.

[30].Paturde J.T., Wankhade S.G., Khode P.P., Chatol P.U., Deo D.D. and Bhuyar S.A. 2002, Effect of organic manures and plant population on yield of safed mushli (Chloraphytum borivallianum). Agricultural Science Digest, 22 (1): 51-52.

[31].Paul, E.A., 2007, Soil microbiology, ecology and biochemistry. $3^{\text {rd }}$ ed. Academic Press, San Diego, CA, 532.

[32].Phule K.G. 1993, Effect of vermiculture farming in sugarcane. Proceedings of congress on traditional science and technologies of India. 28 November - 3 December, Bombay, pp.6-12.

[33].Rachel D.K.V., Kiranmayi D.P., Sirisha G.V.D., 2015, Quality enhancement studies of growth and nutrient content in Phaseolus aureus, Spinacia oleracea and Ocimum sanctumusing Local BioFertilizers. J. Nat. Sci., 3: 17-32

[34].Rajalekshmi K., Pushkala S., and Padmaja P., 1997, Hydrolic characters and available nutrients in oxisol as influenced by vermicompost / vermiculture. Proceedings ninth Kerala science congress, January 1997, Science and technology and environmental department, Thrissur, pp.118-120.

[35].Rajasekaran S., Sundaramoorthy P., Ganesh K.S., 2015, Effect of FYM, N, P fertilizers and biofertilizers on germination and growth of paddy (Oryza sativa L). Int. J. Mar. Atmos. Earth Sci., 35:59-65.

[36].Reddy S., 2010, Organic farming: status, issues and prospects-a review. Agricultural economics Research Review, 23:343-358.

[37].Rowland H.L., Fernsler R.F., Huba J.D. and Bernhardt P.A., 1995, Lightning driven EMP in the upper atmosphere. Geophysical Research Letters, 22(10):1029-95.

[38].Sankari H.S., 2000, Linseed (Linum usitatissimum L.) Cultivars and Breeding Lines as Stem Biomass Producers. Journal of Agronomy and Crop Science, 184: 225-231.

[39].Savci S., 2012, An Agricultural Pollutant: Chemical Fertilizer. International Journal of Environmental Science and Development, 3:73-80.

[40].Slawinski K. and Songin H., 2001, Influence of rates and methods of vermicompost application on the development and yield of Pea. Zeszyty-Naukowe- Adademii- Rolniczei- im- H- Kollata- W-KrakowieSesja- Naukowe (Poland) 75: 57-62.

[41].Sujanya S. and Chandra S., 2011, Effect of part replacement of chemical fertilizers with organic and bio-organic agents in ground nut, Arachis hypogea L. Journal of Algal Biomass Utilization, 2 (4):3841.

[42].Taylor, M., 2012, Flax Profile‘, Published by Agricultural Marketing Resource Centre, Canada.

[43].Vadiraj B.A., Siddagangaiah and Potty S.N., 1998, Response of Coriander (Cariandrum sativum L.) cultivars to graded levels of vermicompost. J. of Spices and Aromatics Crops, 7(2): 141-143.

[44].Waithaka and Dana M.N. 1978, Department of Plant Science and Crop Protection, University of Nairobi. Journal-American-Society-for-Horticulture-Science (USA), 5:627-628. 


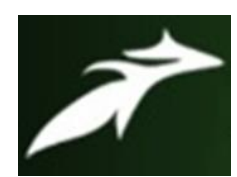

Maneesha Singh et al, International Journal of Advances in Agricultural Science \& Technology, Vol.8 Issue.12, December-2021, pg. 11-31

ISSN: 2348-1358

Impact Factor: 6.057

NAAS Rating: 3.77

1. Dr. Maneesha Singh: The author is Aluminous of Lucknow University, recently working as Dean (Professor), School of Agricultural Sciences, Shri Guru Ram Rai University, Dehradun, Uttarakhand, India, having teaching and research experience of about 20 years, published more than 55 research papers in National and International Journals, Proceedings, published 03 Books and presented 30 abstract papers in conferences/ symposium/ workshops. Granted one US Patent: peppermint plant named "Pranjal" U.S - patent No. 6 of 844 (pp 14,090) granted on August26, 2003 and released 3 varieties of MAPs 'Pratik' of Mentha gracilis X Sole cardiac, 'Pranjal' of Mentha X piperita and 'Prabal' of Catharanthus roseus in CIMAP, Lucknow, Uttar Pradesh. She has completed her Ph.D. program from Central Institute of Medicinal and Aromatic Plants and Lucknow University, Lucknow and field of specialization is Genetics and Plant Breeding (Botany). She has knowledge of conservation and cultivation of Medicinal and Aromatic Plants in vitro and in vivo. She has been awarded with Dr. J. S. Pruthi award for best research paper and selected for Women Scientist Fellowship Scheme for societal program (WOS-B) under DST Department during 2009.

2. Miss Deeksha: The author was born on 7 July 1998 at Barkot Uttarkashi. She passed her high school Suman Grammar high school (2013) Barkot Uttarkashi and Intermediate examination (2015) from Government Girls Inter College Barkot Uttarkashi Uttarakhand respectively. Thereafter in the year 2015 she was admitted to Shri Guru Ram Rai (P.G) College Dehradun, Uttarakhand from where she was completed her B.Sc. Agriculture in 2019 subsequently in the same year, she joined the S.G.R.R. University Dehradun, Uttarakhand for M.Sc. (Ag) in the Department of Agronomy.

3. Babita Bharti: The author was born on 30 June 1998 at Gopeshwar (Chamoli). She passed her high school and Intermediate examinations from Government Girls Inter Collage Gopeshwar (Chamoli) Uttarakhand in 2013 and 2015, respectively. Thereafter in the year 2015 she was admitted to Uttaranchal Institute of Technology, Dehradun, Uttarakhand from where she was completed her B.Sc. (Ag) in 2019 subsequently in the same year she joined the S.G.R.R University Dehradun, Uttarakhand for M.Sc. (Ag) in the Department of Agronomy. 